\title{
Population Fluctuation of Zigzag Leafhopper, Recilia dorsalis in Rice Ecosystem
}

\author{
P. Valarmathi ${ }^{1 *}$ and D. Ladhalakshmi ${ }^{2}$ \\ ${ }^{1}$ ICAR-Central Institute for Cotton Research (CICR), Coimbatore-641 003, India \\ ${ }^{2}$ Department of Plant Pathology, ICAR-Indian Institute of Rice Research (IIRR), \\ Hyderabad-500 030, India
}

*Corresponding author

\section{A B S T R A C T}

\section{Keywords}

Rice orange leaf phytoplasma,

Zigzag leafhopper, Population dynamics

Article Info

Accepted:

12 December 2018

Available Online:

10 January 2019

\section{Introduction}

Rice Yellow Dwarf (RYD), a serious problem for rice farmers, has only been detected to date in Asia, where it is recorded from most rice-growing countries (Nakashima et al., 1993). Infected rice turns pale yellow and gradually starts to decay and produce numerous tillers. Sometimes only a faint mottling occurs. Plants infected early normally do not die but produce abnormal heads or no heads, and ultimately show stunted growth and fail to produce grain (Jung et al., 2003). For many years, the agent associated with RYD was believed to be a virus, until it was identified as a phytoplasma, designated as a 'Candidatus Phytoplasma oryzae' (Jung et al., 2003).

Rice Orange Leaf (ROL) Phytoplasma was widely distributed in South and South-east Asia (Hibino et al., 1987), including Thailand, Malaysia, Indonesia, China, Sri Lanka and the Philippines. Symptoms are typified by orange-coloured leaves, which later roll inward and desiccate. Infected plants die 2-3 weeks after symptoms appear. The diseased plants are generally distributed sporadically in the field, and the disease does 
not cause serious yield loss. ROL was associated with a phytoplasma in Thailand, Malaysia, Indonesia and the Philippines (Hibino et al., 1987) following electron microscopy evidence. Recently, on the basis of the symptoms and on 16SrDNA sequence identity and phylogenetic relationships, the association of 'Candidatus Phytoplasma asteris' with ROL disease in South India was confirmed (Valarmathi et al., 2013). Valarmathi et al., 2015a studied the phytoplasma infecting rice as ' $\mathrm{Ca}$. P. asteris' and belongs to $16 \mathrm{SrI}-\mathrm{B}$ subgroup and reported in rice as a new host of 'Ca. P. asteris' in India and its new vector, Recilia dorsalis for the first report in South Asia. Moreover in India, the 'Candidatus Phytoplasma asteris' is the major group reported to be associated with a wide host range of plant species including agricultural crops, ornamentals, tree and weed species (Azadvar et al., 2009). Valarmathi et al., 2017 characterized 16SRI-B sub group phytoplasma associated with Rice Orange Leaf Phytoplasma through RFLP studies. Valarmathi et al., 2015b studied the detection of Rice Orange Leaf phytoplasma in the Zigzag leafhopper vector, Recilia dorsalis (Motschulsky): a first report through nested PCR. In the present study, the population dynamics of Zigzag Leafhopper (ZLH) in rice ecosystem was studied to know the status of Rice Orange Leaf phytoplasma infecting rice.

\section{Materials and Methods}

The insects were collected on yellow sticky traps placed in the rice fields located at Paddy Breeding Station during the cropping seasons of the year, 2012-2013 with the total cropped area of 1.3 acres. The insects were collected from the rice field during the evening hours from 7.00 P.M. to 8.30 P.M. twice a week from light traps and the numbers were also included along with the population collected from yellow sticky traps to know the distribution of Zigzag leaf hopper in rice ecosystem. Epidemiological factors like
Maximum temperature $\left({ }^{\circ} \mathrm{C}\right)$, minimum temperature $\left({ }^{\circ} \mathrm{C}\right)$, relative humidity $(\%)$ and Rainfall (mm) observations were recorded from the Agro Climate Research Center, TNAU, Coimbatore.

\section{Results and Discussion}

\section{Population dynamics of the vector, zigzag leafhopper in rice ecosystem}

The population dynamics of zigzag leafhopper were observed during the month of October, 2012 till the month of November, 2013 to know the distribution of vector in rice ecosystem (Table 1; Fig. 1). The highest ZLH population was observed during August, 2013 and the lowest in December, 2012. ZLH population decreased gradually from October to December, 2012 and increased in January, 2013. Then population fluctuates in February and March, 2013 and increased by the month of April, 2013. ZLH population again remains decreased from May till July, 2013 and increased during August, 2013. The observed population of ZLH fluctuated due to the fluctuation in climatic factors. The lowest ZLH population during November and December, 2012 and June, 2013 were claimed due to the lowest maximum temperature recorded in these months. Whereas in the month of August, 2013 in spite of lowest maximum temperature, the $\mathrm{ZLH}$ population was observed to be more in number. The presence of viruliferous vectors of green leafhopper was the most important factors causing Tungro epidemic. Savary et al., (1993) concluded that inoculum, as measured by infective vectors, has a greater influence on Tungro outbreaks in the non-endemic than in the endemic areas of Philippines. In nonendemic area of Philippines, Tungro outbreaks were mainly associated with the occurrence of infective vectors and the size of the green leafhopper population has less influence. 
Table.1 Population dynamics of Zigzag leafhopper in rice ecosystem

\begin{tabular}{|l|l|c|c|c|c|c|}
\hline $\begin{array}{c}\text { S. } \\
\text { No }\end{array}$ & $\begin{array}{c}\text { Month and year } \\
\text { of collection }\end{array}$ & $\begin{array}{c}\text { Number of } \\
\text { individuals } \\
\text { collected (yellow } \\
\text { sticky trap+ light } \\
\text { trap) }\end{array}$ & $\begin{array}{c}\text { Maximum } \\
\text { temperature } \\
\left({ }^{\circ} \mathbf{C}\right)\end{array}$ & $\begin{array}{c}\text { Minimum } \\
\text { temperature } \\
\left({ }^{\circ} \mathbf{C}\right)\end{array}$ & $\begin{array}{c}\text { Relative } \\
\text { humidity } \\
(\%)\end{array}$ & $\begin{array}{c}\text { Rainfall } \\
(\mathrm{mm})\end{array}$ \\
\hline 1. & October, 2012 & 70 & 30.48 & 21.27 & 75.54 & 232.50 \\
\hline 2. & November, 2012 & 45 & 30.27 & 19.63 & 74.81 & 61.00 \\
\hline 3. & December, 2012 & 35 & 30.17 & 18.39 & 68.03 & 9.50 \\
\hline 4. & January, 2013 & 120 & 31.11 & 16.87 & 59.95 & 0.00 \\
\hline 5. & February, 2013 & 75 & 31.86 & 14.49 & 59.39 & 16.00 \\
\hline 6. & March, 2013 & 85 & 33.16 & 20.02 & 54.62 & 0.00 \\
\hline 7. & April, 2013 & 135 & 35.42 & 22.43 & 61.49 & 10.00 \\
\hline 8. & May, 2013 & 55 & 34.54 & 23.81 & 60.28 & 72.00 \\
\hline 9. & June, 2013 & 40 & 28.04 & 24.16 & 67.32 & 74.50 \\
\hline 10. & July, 2013 & 85 & 27.31 & 23.78 & 69.02 & 73.00 \\
\hline 11. & August, 2013 & 175 & 29.27 & 23.10 & 68.11 & 59.50 \\
\hline 12. & September, 2013 & 75 & 29.72 & 22.68 & 69.26 & 141.50 \\
\hline 13. & October, 2013 & 90 & 30.65 & 20.62 & 68.25 & 92.00 \\
\hline 14. & November, 2013 & 65 & 30.00 & 19.10 & 80.30 & 71.50 \\
\hline
\end{tabular}

Fig.1 Dynamics of zigzag leafhopper infecting rice

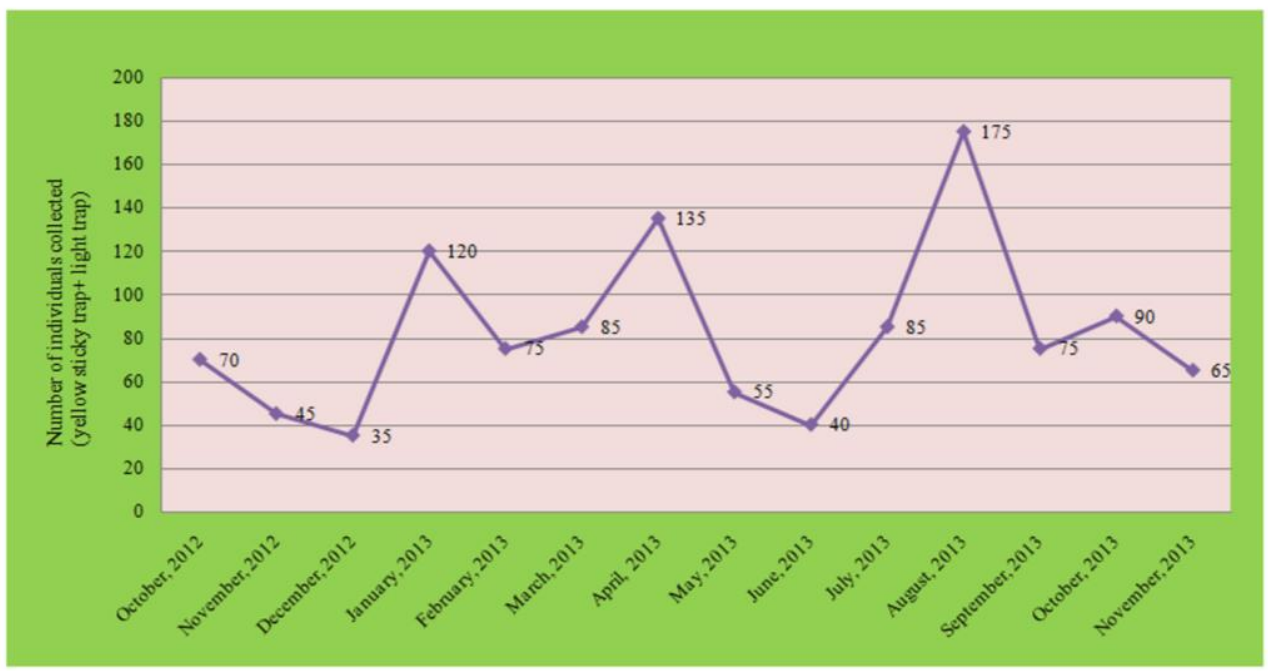

In the two Tungro endemic areas, increasing Tungro incidence was also associated with a larger number of infective vectors but the size of the leafhopper population was also important. Studies on the fluctuation population of green leafhopper (GLH) were conducted monthly by planting of rice in experimental field in Lanrang from May, 2004 until April 2005 by Praptana et al., (2005). They observed that the highest GLH 
population was in August, 2004 and lowest was in January, 2005. GLH population decreased gradually from May to July and increased in August, 2004 then gradually declined in September to March, 2004 and increased in April, 2005.

In order to predict precisely the future dynamics of populations of leafhoppers, the underlying mechanism of population dynamics should be known. Yamamura et al., (2006) found that the observed number of light-trap catches of GLH increases with increasing temperatures in the previous winter. They also indicated that the influence of temperature is not carried over to the next year. Wherein the studies by Andrewartha and Birch (1954) found that the fluctuation in the observed population of leafhoppers is influenced by the climatic fluctuation. Based on the above study, the population dynamics of Zigzag leafhopper (ZLH) were observed between the month of October, 2012 till the month of November, 2013 to know the distribution of vector in rice ecosystem at Paddy Breeding Station, Coimbatore. The highest ZLH population was observed in August, 2013 and the lowest was in December, 2012 as similar to the population of GLH observed by Praptana et al., (2005). ZLH population decreased gradually from October to December, 2012 and increased in January, 2013. Then population fluctuated during February and March, 2013 and increased by the month of April, 2013. ZLH population again remains decreased from May till July, 2013 and increased by August, 2013.

The observed population of ZLH fluctuated due to the climatic variation. The lowest ZLH population during November and December, 2012 and June, 2013 were claimed to the lowest maximum temperature recorded in these months. Wherein by the month of August, 2013 inspite of lowest maximum temperature recorded, the ZLH population was observed to be more in number. The factors such as the presence of rice crop at nursery stages and also the continuous rain over the previous months of June and July contributed for the maximum population of $\mathrm{ZLH}$ in rice ecosystem. Hence, the present population dynamics of ZLH will be helpful to predict the future population status of $\mathrm{ZLH}$ to know the distribution of rice orange leaf phytoplasma disease in the rice ecosystem.

\section{References}

Andrewartha, H. G. and Birch, L. C. 1954. The distribution and abundance of animals. Chicago Press, Chicago, IL.

Azadvar, M., Baranwal, V.K. and Yadav, D.K. 2009. First report of a 16SrIX (pigeon pea witches' broom) phytoplasma associated with toria (Brassica rapa cv. toria) phyllody disease in India. New Dis. Rep., 20: 27.

Hibino, H., Jonson, G. B. and Sta Cruz, F. C. 1987. Association of mycoplasma-like organisms with rice orange leaf in the Philippines. Plant Dis., 71: 792-794.

Jung, H. Y., Sawayanagi, T., Wongkaew, P., Kakizawa, S., Nishigawa, H., Wei, W., Oshima, K., Miyata, S., Ugaki, M., Hibi, T. and Namba, S. 2003. 'Candidatus Phytoplasma oryzae', a novel phytoplasma taxon associated with rice yellow dwarf disease. Int. J. Syst. Evol. Microbiol., 53: 1925-1929.

Nakashima, K., Kato, S., Iwanami, S. and Murata, N. 1993. DNA probes reveal relatedness of rice yellow dwarf mycoplasma like organisms (MLOs) and distinguish them from other MLOs. Appl. Environ. Microbiol., 59: 12061212.

Praptana, H. R., Bastian, A., Fausiah, T. L. and Muliadi, A. 2005. Population fluctuation of Green leafhopper, Nephotettix virescens and their predators. Rice Tungro disease research 
station. Lanrang. pp. 519-522.

Savary, S., Fabellar, N., Tiongco, E. R. and Teng, P. S. 1993. A characterization of rice tungro epidemics in the Philippines from historical survey data. Plant Dis., 77: 376-382.

Valarmathi, P., Ladhalakshmi, D. and Rabindran, R. 2017. Characterization of a 16SRI-B sub group phytoplasma associated with Rice Orange Leaf Phytoplasma through RFLP studies. Progressive Research- An International Journal., 12 (I): 713-716.

Valarmathi, P., Velazhahan, R., Suresh, S., Robin, S., Rabindran, R. and G. P. Rao. 2015a. Subgroup level identification of rice orange leaf phytoplasma and its natural transmission through zigzag leafhopper (Recilia dorsalis) in India. Phytopathogenic Mollicutes., 5(2): 107112.
Valarmathi, P. and Rabindran, R. 2015b. Nested PCR assay for detection of Rice Orange Leaf phytoplasma in the Zigzag leafhopper vector, Recilia dorsalis (Motschulsky): a first report. The Ecoscan., 9(3\&4): 837-839

Valarmathi, P., Rabindran, R., Velazhahan, R., Suresh, S. and Robin, S. 2013. First report of rice orange leaf disease phytoplasma (16SrI) in rice (Oryza sativa) in India. Australas Plant Dis. Notes., 8: 41-43.

Yamamura, K., Yokozawa, M., Nishimori, M., Ueda, Y. and Yokosuka, T. 2006. How to analyze long-term insect population dynamics under climate change: 50-year data of three insect pests in paddy fields. Popul. Ecol., 48: $31-48$.

\section{How to cite this article:}

Valarmathi, P. and Ladhalakshmi. 2019. Population Fluctuation of Zigzag Leafhopper, Recilia dorsalis in Rice Ecosystem. Int.J.Curr.Microbiol.App.Sci. 8(01): 1589-1593. doi: https://doi.org/10.20546/ijcmas.2019.801.167 